Анна Нікоґосян

\title{
Привласнення фемінізму: ґендер, мілітаризм і Резолюція ООН 1325
}

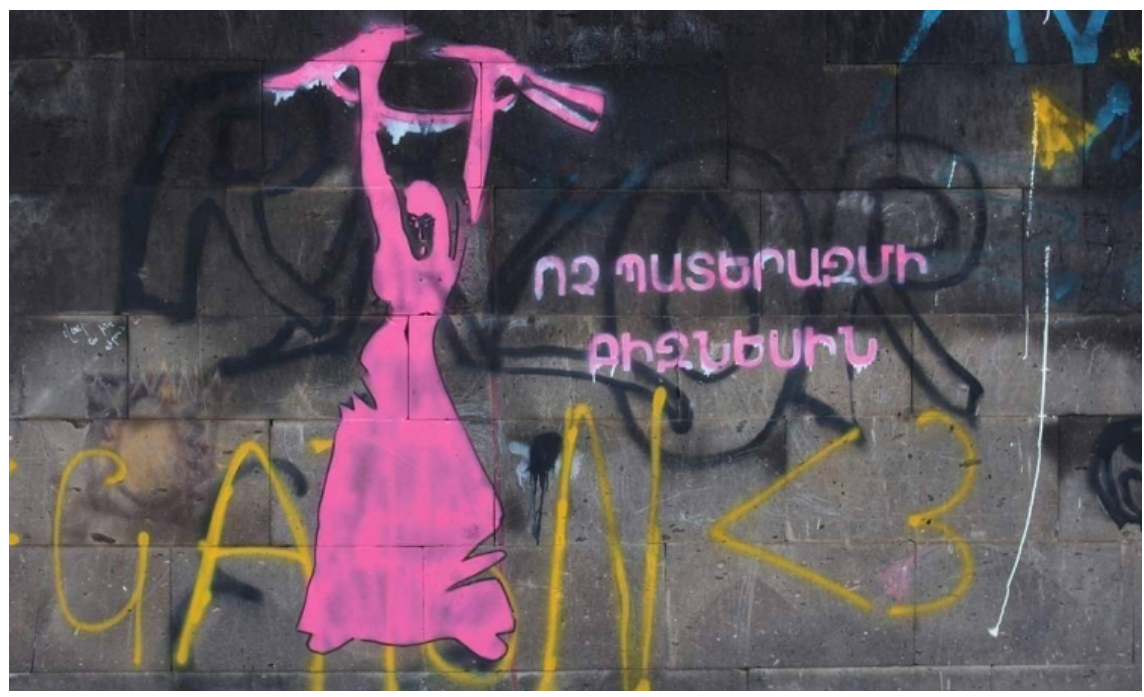

\section{Ґендер, війна та мілітаризм у дискурсивній перспективі}

$\mathrm{P}$ езолюцію 1325, ухвалену Радою Безпеки ООН (надалі - Резолюція 1325 або Резолюція), часто називають поворотною та революційною подією (Cohn 2008; Shepherd 2015). Уперше така вкрай маскулінізована інституція як Рада Безпеки ООН безпосередньо звернула увагу на питання жінок і збройних конфліктів. Ця подія позиціонувала жінок і збройні конфлікти як рівноважливі та визнала необхідність участі жінок у процесах побудови миру й у прийнятті рішень щодо запобі-

Перекладено з дозволу авторки за: Anna Nikoghosyan. “Co-Optation of Feminism: Gender, Militarism and the UNSC Resolution 1325." Feminist Critique: East European Journal of Feminist and Queer Studies 1 (2018): 7-18. Наукова редакторка перекладу Марія Маєрчик.

На знимці: «"Ні" військовому бізнесу» - нині вже знищене графіті авторства Арпі Балаян у місті Ґюмрі (Вірменія).

(c) Наталка Чех, переклад, 2019

(C) Anna Nikoghosyan, 2018

(C) Критика феміністична: східноєвропейський журнал феміністичних і квір-студій 2019, № 2, с. 30-41 http://feminist.krytyka.com (ISSN 2524-2733) 
гання конфліктам і їх вирішення (United Nations Security Council 2000). У жовтні 2015 року до п'ятнадцятиріччя Резолюції 1325 було розпочато Глобальне дослідження Резолюції (UN Women 2015). У ньому зазначено: «Жінки, мир і безпека - це про попередження війни, а не про те, щоби війна була безпечнішою для жінок» (Coomaraswamy 2015, 191). Та, попри цю важливу заяву, дискусії навколо Резолюції показують, що вона не лише не здатна просувати антивоєнну феміністичну програму, але що іï саму використовують у мілітаристських цілях, перетворюючи їі радикальний потенціал на інструменталізовану, привласнену феміністичну програму.

У цій статті я в руслі феміністичних антимілітаристських дискусій вивчаю, як дискурс ґендерної безпеки у структурах ООН підтримує процес війни. Зокрема, я стверджую, що Резолюцію 1325 було створено через ґендеровані дискурси, і це уможливило її використання в мілітаристських цілях. Опираючись на постструктуралістську феміністичну теорію, я розглядаю Резолюцію як дискурсивну практику та стверджую, що те, як понятійний апарат $00 \mathrm{H}$ розуміє й інтерпретує концепти ґендеру і безпеки, призводить до замовчування антимілітаристської критики та створює умови для привласнення державами радикального змісту Резолюції шляхом легітимації й нормалізації мілітаристської практики.

Я пропоную вийти за межі звичайного поляризованого розуміння війни і миру та зосередити увагу на мілітаризації як ширшому та складнішому процесі «творення» війни. Для розуміння, як Об'єднані Нації інтерпретують гендерну безпеку, уможливлюючи практики мілітаризації, важливо звернути увагу на дискурси. Крістін Сільвестр пропонує тезу: «Війна - це політика травмування: усе в ній націлене на те, щоби кривдити людей і псувати їхнє соціальне середовище» (Sylvester $2012,3-4)$. Війна як «політика травмування» $є$ глибоко гендерованою активністю (Parashar 2015, 100), яка створює умови для політичного плекання певного типу «мілітаризованої маскулінності» (Enloe 2000, 100). Війна - систематична та континуальна (Cockburn 2015, 114). Ця континуальність полягає в циклі мілітаризму, процесові мілітаризації, епізодів «гарячих боїв» і угоди щодо припинення вогню, на зміну яким приходять нестійкий мир, супроводжуваний постійними інвестиціями у збройні сили, і безперервне насильство (Cockburn 2004). Аби врахувати складність, розмитість і багатоманітність виявів і досвідів війни, у цій роботі я виходжу за межі традиційного, поляризованого розуміння війни і миру. На основі концепції мілітаризму, сформульованої Синтією Енло (Enloe 2014; Enloe 2000), я розглядаю дискурс гендерної безпеки як такий, що підтримує радше мілітаризацію, ніж війну, де під мілітаризацією я розумію набір взаємопов'язаних процесів, що роблять феномен війни легітимним і нескінченним.

Синтія Енло каже, що мілітаризм $є$ «поступовим процесом, упродовж якого людина чи річ крок за кроком стає контрольованою армією, або ж їі благополуччя починає залежати від мілітаристських ідей (Enloe 
2000, 3). Як стверджують Лора Сйоберг та Сандра Вія (Laura Sjoberg, Sandra Via), «мілітаризм - це розростання смислів та дій, пов'язаних із війною або з її підготовкою, поза межами “війни як такої"» (Shepherd $2016,2)$. У рамках культури війни і миру мілітаризація породжує чимало різних малопомітних форм і явищ; тож хоч Резолюція 1325 від початку й мала за мету підважити патріархальний порядок, незабаром вона сама стала однією з прихованих тактик маскулінізованої мілітаризації.

Украй важливо простежити, як у зв'язку зі створенням та впровадженням Резолюції 1325 вироблялися значення ґендеру та ґендерної безпеки. Спираючись на теорію Джудит Батлер (1990) про ґендер як «роблення», а не «буття», я розглядаю гендер як перформативне і сутнісно мінливе явище (McLeod 2016, 17). За Батлер, «гендер - це завжди роблення, проте не можна сказати, що це роблення суб'єкта, який передує самій дії» (Butler 1990, 25). Гендерна перформативність означає, що гендер це результат дискурсів. Людське суспільство виробляє певні практики та знання через гендеровані дискурси, які мають продуктивну потенцію влади, а це означає, що власне ці дискурси породжують і формують самих суб'єктів. Тож інтерпретація гендеру в понятійному апараті $00 \mathrm{H}$ це ключ до розуміння того, як були створені та впроваджені на практиці дискурсивні політики. Інакше кажучи, які дії ці дискурси натуралізують, а які лишають незауваженими.

Дискурси в діяльності ООН важать так, як «мова важить у політиці» (Shepherd 2010, 144). Лора Шеферд показує: аби зрозуміти, як краще запровадити певний політичний принцип, потрібно з'ясувати не лише що́ цей політичний принцип означає, але також як сформувалося це значення (Shepherd 2010, 144). Вона вважає, що дискурси - «це радше системи виробництва значень, ніж просто твердження чи мова» (Shepherd $2010,156)$. Продовжуючи цю думку, я обстоюю тезу, що понятійна організація Резолюції уможливлює певні нормативні розуміння «безпеки» та «роблення» гендеру й унеможливлює деякі інші. Пов'язані з Резолюцією 1325 ціннісно орієнтовані значення важать для ії впровадження. Відповідно, розглядаючи Резолюцію як дискурсивну практику, яка уможливлює певне розуміння ґендеру, війни і миру й унеможливлює інші, ми повинні спершу критично проаналізувати, як концепція Об'єднаних Націй щодо ґендеру та безпеки вплинула на формування змісту та впровадження Резолюції.

Як стверджує Лора Маклеод, кожен конкретний підхід до гендерної безпеки спирається на певну концепцію «гендеру» та «безпеки» (McLeod 2011, 595). Позаяк концепція $\epsilon$ «сутнісно політичною», це означає, що деякі а́ктори можуть використати концептуалізацію гендеру та можливості, створені цим конкретним дискурсом, для своїх цілей, здійснюючи відповідну політичну інтерпретацію принципів і документів 0ОН. Отже, те, як гендер та ґендерну безпеку представлено в архітектурному оонівському дискурсі побудови миру, уможливлює та легітимує певні дії держав (як-от підтримку процесу постійної мілітаризації) 
й унеможливлює інші дії (наприклад, антивоєнну та антимілітаристську критику). У подальших розділах я спочатку проаналізую ґендерні дискурси, що лежать в основі Резолюції, а далі розгляну два основні шляхи мілітаризації Резолюції. Перший шлях- це ототожнення ґендеру 3 «жінками, які потребують захисту». Цей підхід виправдовує іноземне військове вторгнення та «гарантує» захист через розбудову армії. Другий - зростання залученості жінок до сектору безпеки та збройних сил в ім'я жіночої «участі» у постконфліктній відбудові. У підсумку я обстоюю думку про критичну важливість дискурсивного аналізу Резолюції 1325, адже він демонструє, як документ, що мав субверсивний потенціал для протидії мілітаризованому патріархату, посилює саме ті владні структури, які був покликаний зруйнувати.

\section{Зробити війну безпечною для жінок: Резолюція 1325 та її історія}

Після прийняття Резолюції 2000 року Рада Безпеки додала до неї ще шість резолюцій, які всі разом сформували програму ООН «Війна, мир і безпека» (Shepherd 2015, 273). Ця програма має три основні складові: захист, запобіганнята залучення. У цьому розділі я зосереджуся на двох із них - «захисті» та «залученні», що держави використовують для збільшення потужностей військових комплексів і задіювання більшої кількості людей до військово-оборонних інституцій.

Йдеться про те, що Резолюція 1325 пропонує звичайне оонівське розуміння людської безпеки, а саме, що держава гарантує безпеку, що безпека - це відсутність конфлікту та щось таке, чого можна досягти (Shepherd 2008, 127; McLeod 2016, 37; Zajović 2010). Як наголошено у самій Резолюції, згідно зі Статутом ООН, першочерговою відповідальністю Ради Безпеки $є$ «підтримка міжнародного миру та безпеки» (United Nations Security Council 2000). За такою логікою, Резолюція 1325 почала інтерпретувати гендерну безпеку як розширену версію загальнолюдської і сформулювала її у спосіб, що не підважує конвенційного розуміння безпеки, відповідно до якого гарантками (державної) безпеки $\epsilon$ військові інституції. Ба більше, для багатьох феміністок-пацифісток Резолюція 1325 стала проблемною ще й тому, що вона не проблематизує наявні владні структури та приймає логіку системи війни (Cohn 2008; Cockburn 200). I хоча Резолюція прямо закликає до захисту жінок від насильства, залучення їх до миротворчої діяльністі та вирішення конфліктів, у ній немає жодного рядка про запобігання війнам чи мілітаризмові як такому. Отже, Резолюція апріорі приймає існування воєн, натуралізує необхідність мілітаризації й не ставить ці явища під сумнів, натомість докладаючи зусиль, щоби зробити цю неуникну війну безпечнішою бодай для жінок. На основі аналізу історії Резолюції, стає зрозуміло, що «гендерну безпеку» було концептуалізовано без підважування мілітаризму та війни. 
2000 року під час засідань Комісії ООН про становище жінок було створено недержавну громадську організацію «Робоча група з питань жінок, миру та безпеки», метою якої було просувати прийняття Резолюції (Cohn 2008, 4). Процес розробки документа вимагав значних зусиль багатьох груп, здебільшого об’єднаних у різні неурядові організації. I попри цю значну підготовчу групову роботу, аналіз покладених в основу Резолюції ключових цінностей та первинних цілей оприявнив кілька важливих фактів. Більшість організацій, що входили до складу «Робочої групи...», не поділяли ані антивоєнних, ані феміністичних поглядів (Cohn 2008, 12). Із шести організацій «Робочої групи...» тільки Міжнародна жіноча ліга за мир і свободу чітко ідентифікувала себе як феміністична, антивоєнна й антимілітаристична організація і наполягала на обговоренні політичних питань (Cohn 2008, 12). Учасниці організації пропонували включити до обговорення питання міжнародної торгівлі зброєю, мілітаризму та його взаємозв'язку з маскулінністю, але це визнали «занадто політичним». Тобто питання щодо причин збройних конфліктів визнали занадто радикальним для Резолюції.

Відсутність цих питань у ній свідчить про те, якими єдискурсивні практики програми «Війна, мир і безпека»: схоже, вони просто повторюють типові практики інституцій із гарантування міжнародного миру та безпеки, для яких державна безпека досягається військовими засобами. Як наслідок, Резолюція захищає жінок на війні, - мовляв, тепер вони мають рівні права брати участь у припиненні конкретних воєн, - але не зачіпає війну як таку. Резолюція 1325 не підважує існування війни як системи та функціонування військово-оборонного комплексу, і в такий спосіб легітимує їх. А втім, було би наївно сподіватись, що сама лише Резолюція може підважити існування війни як такої. Коли 80\% прибутку від міжнародної торгівлі зброєю іде до п’яти постійних членів Ради Безпеки (Cohn 2008, 18), питання про те, як на практиці Рада Безпеки може виступати проти війни, стає безглуздим.

Резолюція обходить увагою не лише війну, а й мілітаризовану маскулінність. Тут нема ні слова про чоловіків і маскулінну культуру насильства (Cockburn 2013, 444). Текст Резолюції нормалізує ідею про те, що насильство стосовно жінок і дівчат існуватиме завжди, а отже існує постійна потреба «захищати права жінок і дівчат під час і після конфліктів» та «захищати жінок і дівчат від ґендерно зумовленого насильства, особливо від зґвалтування й інших форм сексуальних злочинів» (United Nations Security Council 2000). Тобто Резолюція не кидає виклик патріархату, вона не містить критики патріархальної системи чоловічого домінування. У наступних розділах я покажу, що Резолюція не лише не змогла підважити логіку війни, але була привласнена й інструменталізована з мілітарною метою. Я пропоную розглянути два способи, уякі відбувається мілітаризація Резолюції. Перший - через ототожнення ґендеру 3 «жінками, що потребують захисту» (частина про «захист» у програмі $\mathrm{OOH}$ «Війна, мир і безпека»). Другий - через забезпечення «участі» жі- 
нок у післявоєнній відбудові шляхом залучення їх до сектору безпеки й армії (частина про «безпеку»).

\section{«Своєю зброєю вони врятують вас»: ґендер як «захист жінок»}

Як завважує Надін Пучгайрбал, у мові ООН жінок зображено здебільшого жертвами, які потребують захисту (Puechguirbal 2015, 254). Тож, попри свою революційність, Резолюція продовжує послуговуватися тією ж мовою віктимізації. Резолюція, «виражаючи занепокоєння тим, що цивільні люди, зокрема, жінки та діти складають вагому частку потерпілих від збройного конфлікту» і визнаючи дієвість «ефективних інституційних заходів із забезпечення захисту [жінок]», здійснює кроки для «забезпечення захисту та поваги до прав людини жінок і дівчат» та «захисту жінок і дівчат від ґендерно зумовленого насильства, зокрема, згвалтування й інших форм сексуальних злочинів і всіх інших форм насильства в ситуації збройного конфлікту», а також закликає «брати до уваги особливі потреби жінок і дівчат» (Рада Безпеки ООН 2000). Жінок у Резолюції також асоціюють із дітьми, таким чином позначаючи їх як безпорадних і вразливих осіб. Направду, як каже Синтія Енло, «збройні сили зіперто як на жінок, так і на зверхність щодо фемінності» (Enloe 2000, x; Enloe 2010, 3). Тож Резолюція посилює уявлення про (мілітаризованих) чоловіків як норму і як «захисників», водночас жінки постають як «інші» - безпорадні, «захищені», «жінки-та-діти».

Один зі шляхів упровадження Резолюції 1325 - формування Плану національної безпеки. Лора Шеферд проаналізувала Плани національної безпеки шести країн: Австралії, Грузії, Німеччини, Італії, Великобританії та США. Результати показують, що ці Плани зосереджені здебільшого на «захисті жінок» і на «безпечності війни» для жінок. У Планах деяких країн, - зокрема, США, Великобританії й Австралії, - узагалі йдеться про війну та незахищеність на закордонних, а не власних територіях (Shepherd 2016, 1). Це стимулює ідею зовнішньо-територіальних інтересів і мостить дорогу для зовнішніх (військових) інтервенцій.

Одрі Рівз звертається до концепту урядувальництва [governmentality], запропонованого Мішелем Фуко, і вказує, що оонівський урядувальницький дискурс миротворчості створює підгрунтя для військових вторгнень у постколоніальний світ (Reeves 2012, 350). Тобто дискурс незахищених жінок може підтримувати глобальні ієрархії та заохочувати «колоніальний фемінізм» (Al-Ali and Pratt 2009a). Скажімо, Резолюцію 1325 було використано у преамбулі до Резолюції 1483, ухваленої Радою Безпеки щодо Іраку, хоч, зверну увагу, залучення жінок до відбудови було використано саме задля виправдання риторики «звільнення» пригнічених жінок під час військової окупації (Cohn et al. 2004, 138). Моггадам вказує також, що до Резолюції апелюють у разі «глобальної війни з терором» (Moghadam 2015, 339). Тож колоніальне мислення та 
практики й далі продовжують працювати в ім'я захисту (Agathangelou and Turcotte 2015,43 ). Ігноруючи перетини класу, етнічності, національності, сексуальної орієнтації, ґендерної ідентичності й інших важливих аспектів, Резолюція 1325 продовжує відтворювати «західний білий гетеронормативний фемінізм» (Santos, Roque, and Moura 2013; Pratt 2013) і не здатна залучити інтерсекційні та постколоніальні феміністичні підходи, аби підважити капіталізм, неоколоніалізм чи імперіалізм.

Деякі держави свідомо використовують риторику Резолюції 1325 щодо захисту жінок і частину про «безпеку» у програмі «Війна, мир і безпека» з мілітаристськими, імперіалістичними чи неоколоніальними цілями. Гендер в ООН інтерпретують як «жінок, що потребують захисту», а гендерну безпеку, відтак, поміщають у рамки конвенційного державоцентричного мілітаризованого розуміння безпеки. А отже те, як ґендер і логіка ґендерної безпеки працюють у контексті Резолюції і як ООН їх інтерпретує, є засадничо важливим, бо присвоєння Резолюції здійснюється саме внаслідок цих маніпуляцій дискурсивними репрезентаціями. Захист, однак, не єдина застосована для мілітаризації Резолюції стратегія. У наступній частині статті я на прикладі Вірменії показую, як участь жінок нормалізує мілітаристські наміри держав і залишає маскулінну владу непідваженою.

\section{«Ми зможемо!» Залучення жінок до сектору безпеки та збройних сил}

Аби «збільшити вплив [жінок] на прийняття рішень у справі запобігання конфліктам і їх вирішення», Резолюція 1325 «наполегливо закликає держав-учасниць забезпечити зростання представництва жінок на всіх рівнях прийняття рішень у національних, регіональних, міжнародних інституціях і в механізмах запобігання конфліктам і їх вирішення». Резолюція також «заохочує генерального секретаря реалізувати його план стратегічних дій (А/49/587) зі сприяння збільшенню представництва жінок на керівних посадах у структурах із вирішення конфлікту та мирних процесів». Цікаво спостерігати як непропорційно жінки беруть «участь» у вирішенні конфлікту та постконфліктному відновленні Вірменії. Зокрема, порівняймо, з одного боку, доступ жінок до прийняття рішень і перемовин щодо мирних процесів, а з іншого, зростання представництва жінок у військових інституціях. Вивчення справді мізерної кількості даних щодо реалізації цілей Резолюції 1325 показує, що участь жінок у військовому секторі це головна «сфера імплементації» Резолюції 1325 Ради Безпеки, яка зростає вкрай непропорційно супроти динаміки в інших секторах. Скажімо, станом на 2016 рік, серед членів Вірменського національного парламенту зі 131 особи лише 12 - жінки. У країні лише 2 міністерки, і відсоток жінок на міністерських посадах за останні роки не подолав цю позначку (Shahnazaryan 2015). Жінки виключені 3 усіх офіційних переговорів щодо встановлення миру і працюють тільки 
в межах неформальних, менш значущих заходів (The Kvinna till Kvinna Foundation 2012; Goris Women's Development "Resource Center" Foundation at al. 2013). Але погляньмо, що відбувається, коли справа стосується участі жінок у секторі безпеки. У Вірменії відбуваються реформи сектору безпеки, і один із ключових їхніх компонентів - заохотити збільшення там кількості жінок (Armenpress 2015). Так у червні 2013 року міністр оборони Вірменії оголосив, що жінки можуть бути прийняті до двох найбільших військових інституцій країни (Abrahamyan 2013), це згодом назвали значним кроком на шляху до впровадження Резолюції. Отож, у Вірменії впровадження Резолюції 1325 ототожнюється з участю жінок у вірменських структурах захисту та збройних сил. Цезначить, що жінок можна захистити шляхом вирівнювання можливостей, а також вказує, що поняття ґендерної безпеки розглядають крізь призму мілітаризованого розуміння безпеки.

Найяскравіший приклад того, як Вірменія дотримується своїх зобов'язань щодо Резолюції - зміцнення партнерства Вірменії та НАTO 3 метою успішного впровадження Резолюції 1325 (NATO 2016). Насправді просто уважного огляду очікуваних результатів і планів Програми NATO/EAPC 2014-2016 досить, аби помітити активне зростання мілітаризації задля впровадження Резолюції (NATO 2014). Як зазначено в документі, «фундаментальною та довгостроковою метою НАТО є захист свободи й безпеки всіх його учасників політичними та військовими засобами» (NATO 2014). Тим часом привласнення НАTO Резолюції в різних країнах - явище не нове, і феміністки-антимілітаристки неодноразово звертали на це увагу (Cockburn 2009).

У листопаді 2014 року з метою зміцнення союзництва між НАТО та Вірменією в Єревані відбувся «тиждень НАТО», і однією з обговорюваних тем була місцева імплементація Резолюції 1325 Ради Безпеки OOH (Leach 2014; UNFPA 2015). Уже навіть не дивно, що присвячену Резолюції офіційну подію організовували Міністерство оборони, Міністерство закордонних справ і Фонд народонаселення ООН Вірменії, що ще раз продемонструвало мілітаристський і ліберальний підхід до впровадженні Резолюції у Вірменії. Подібні заходи відбувалися також 2015 та 2016 роках. 3 квітня 2015 року міністр оборони Республіки Вірменії приймав спеціальну представницю генерального секретаря НАТО з питань жінок, миру та безпеки, посолку Марієт Шуурман (Marriët Schuurman). На зустрічі обговорювали Резолюцію 1325. Як зазначив міністр оборони, імплементація Резолюції у Республіці відбувається успішно, про що свідчить залучення жінок до сектору оборони та в політику у сфері безпеки, а також зростання числа жінок в інституціях

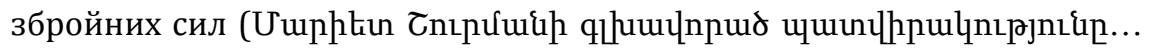
2015). У листопаді того ж року Фонд народонаселення ООН Вірменії, Мiністерство оборони та Міністерство закордонних справ організували семінар з упровадження Резолюції 1325, де були присутні представниці та представники НАТО, різних міжнародних організацій і диплома- 
тії, громадянського суспільства й академії. Пан Ваган Асатрян (Vahan Asatryan), старший експерт у Міжнародному центрі розвитку людини, говорив про підтримані Фондом народонаселення ООН дослідження щодо залучення жінок до сфери оборони Вірменії. Декан факультету прикладної соціології Єреванського державного університету Артур Атанесян (Artur Atanesyan) презентував майбутню книгу «Жінки й армія», у якій ідеться про залучення жінок до збройних сил (UNFPA 2015).

Тож зовсім не дивно, що 2016 року під час «тижня НАТО» у Єревані керівник офісу НАТО на Південному Кавказі Вільям Лах’ю (William Lahue) на події під назвою «Жінки у збройних силах» завважив: «Роль та значущість жінок у збройних силах тривалий час применшувалась, але ООН і НАТО визнають і високо цінують вклад жінок» (Чuquup $Z 2$ qh\{uluð nıł Łnıu... 2016). Ці приклади демонструють, що залучення жінок до безпеки править за головну ціль Резолюції. Зростання кількості жінок у збройних силах і хибне використання Резолюції 1325, утім, не $\epsilon$ зовнішньою інтервенцією глобального мілітаризму. Це радше обопільне зближення, взаємовигідний процес посилення мілітаризації. Згідно 3 прийнятою вірменськими владними елітами програмою «Нація-Армія» (News.am 2016), де націю ототожнено з армією, вірменське суспільство постає суспільством-військом, а жіноче питання - ще одним механізмом посилення націоналістичних і мілітаристських ідей.

Може видатися, ніби залучення жінок до збройних сил свідчить, що імплементація програми «Жінки, мир і безпека» дає державам змогу зробити війну кращою (Shepherd 2016). Але насправді, включення жінок до інституції, чия основна мета - здійснення насильства щодо «інших», аби захистити «своїх» (Al-Ali and Pratt 2009b, 170) - не радикальна дія. Думка, що стратегія «додати жінок і перемішати» може змінити мілітаризовану маскулінність, хибна. Як пише Ганна Райт, «заклики наймати більше жінок справді фемінізують мілітаризм, чи все-таки мілітаризують фемінізм?» (Wright 2015, 505). Це риторичне питання увиразнює той факт, що владні структури, які феміністки хочуть зруйнувати, $\epsilon$ тими самими структурами, що забезпечують доступ жінок до прийняття рішень (Cohn et al. 2004, 138). Таким чином, у рамках Резолюції 1325 жінок залучають до сектору безпеки та збройних сил у спосіб, який не підважує глибоко маскулінізованої культури мілітаризму, а відтак владні структури нерівностей і система війни досі не проблематизовані.

\section{Висновок}

Резолюція 1325 здатна підважити гегемонні гендерні норми та сприяти критичному переосмисленню концепту ґендерної безпеки. У цьому есеї я показую, що, хоч Резолюція й має революційний потенціал, воназаразом продовжує підтримувати систему війни, яку була покликана долати, і в такий спосібперетворює жіночу програму на ще один інструмент для досягнення політичних цілей, встановлених чоловіка- 
ми для чоловіків. Нестача розуміння того, як терміни «гендер» та «ґендерна безпека» сприймало й використовувало ООН, не просто залишає систему війни поза критикою, а й нормалізує війну, працює на користь мілітаризованих а́кторів при владі. Під прапором «захисту» та залучення жінок відбувається використання жіночої програми для посилення владних структур неоліберальної імперії, а отже, мілітаризації не лише не кидають виклик, а навпаки - мілітаризується сам фемінізм.

Власне, проблематизація функціонування апарату безпеки ООН i підважування конвенційної інтерпретації ґендеру та ґендерної безпеки було би кроком уперед. Тим часом, важливо критично осмислювати, яку мову ООН обирає, адже дискурси, спродуковані в такий спосіб, формують політику впровадження Резолюції. Дискурсивні практики формують, виробляють і легітимують певні значення та дії, і саме ці практики нам потрібно підважувати. Я підтримую думку, що Резолюція 1325 не повинна нормалізувати війну та посилювати мілітаризаційні процеси; їі задача - заохочувати демілітаризацію, розвивати антимілітарні політики миру та забезпечувати дискурсивний поворот від конвенційного розуміння мілітаризованої та державоцентричної безпеки до феміністичної концептуалізації миру.

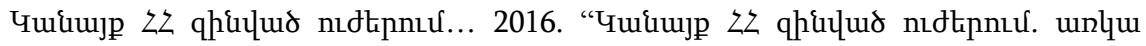

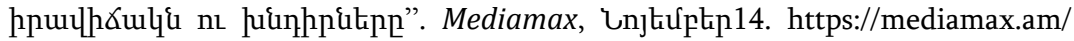
am/news/armypolice/20583/

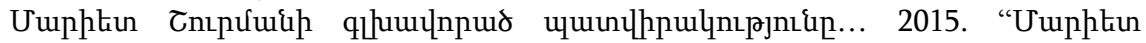

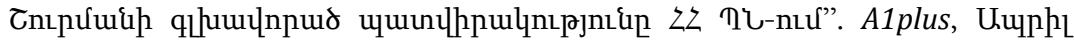
3. http://www.a1plus.am/1375173.html

Abrahamyan, Gayane. 2013. "Armenia: Military Academies Opening Doors to Women." Eurasianet, July 16. http://www.eurasianet.org/node/67254

Agathangelou, Anna, and Heather Turcotte. 2015. "Postcolonial Theories and Challenges to 'First World-ism," Gender Matters in Global Politics: A Feminist Introduction to International Relations, ed. by L. Shepherd, 36-48. New York: Routledge.

Al-Ali, Nadje, and Nicola Pratt. 2009a. Women and War in the Middle East: Transnational Perspectives. London: Zed Books.

Al-Ali, Nadje, and Nicola Pratt. 2009b. What Kind of Liberation: Women and the Occupation of Iraq. Berkeley: University of California Press.

Armenpress. 2015. "Ministry of Defence Encourages Women's Military Service in the Army." Armenpress, August 22. https://armenpress.am/eng/news/816061/ministry-of-defense-encourages-women $\%$ E2\%80\%99s-military-service-in-the-army.html

Butler, Judith. 1990. Gender Trouble: Feminism and the Subversion of Identity. NewYork: Routledge.

Cockburn, Cynthia. 2004. "The Continuum of Violence: A Gender Perspective on War and Peace." Sites of Violence: Gender and Conflict Zones, ed. by Wenona Giles and Jennifer Hyndman, 24-43. Berkley, Los Angeles: University of California Press.

Cockburn, Cynthia. 2007. From Where We Stand: War, Women's Activism and Feminist Analysis. London: Zed Books.

Cockburn, Cynthia. 2009. "Uncovering the Falsehoods of NATO's 'Security': Steps along the Road of a Feminist Peace Activism." International Congress "No to 
NATO," Strasbourg, April 3-5, Contribution to the Workshop "NATO=Security? Gender Questions" http://www.wloe.org/fileadmin/Files-DE/PDF/Themen/ NATO_April_09/CYNTHIAFinal.pdf

Cockburn, Cynthia. 2013. "War and Security, Women and Gender: An Overview of the Issues." Gender and Development 21(3): 433-452.

Cockburn, Cynthia. 2015. "Militarism." Gender Matters in Global Politics: A Feminist Introduction to International Relations, ed. by L. Shepherd, 110-119. New York: Routledge.

Cohn, Carol, Helen Kinsella, and Sheri Gibbings. 2004. "Women, Peace and Security Resolution 1325." International Feminist Journal of Politics 6(1): 130-140.

Cohn, Carol. 2008. "Mainstreaming Gender in UN Security Policy: A Path to Political Transformation?" Global Governance: Feminist Perspectives, ed. by Shirin M. Rai and Georgina Waylen, 185-206. Basingstoke: Palgrave Macmillan.

Coomaraswamy, Radhika. 2015. Preventing Conflict Transforming Justice Securing the Peace: A Global Study on the Implementation of United Nations Security Council Resolution 1325. UN Women.

Enloe, Cynthia. 2000. Maneuvers: the International Politics of Militarizing Women's Lives. Berkeley, California; London: University of California Press.

Enloe, Cynthia. 2010. Nimo's War, Emma's War - Making Feminist Sense of the Iraq War. Berkeley, Los Angeles, London: University of California Press.

Enloe, Cynthia. 2014. Bananas, Beaches and Bases Making Feminist Sense of International Politics. Berkeley: University of California Press.

Goris Women's Development "Resource Center" Foundation, Society Without Violence, Democracy Today, Women's Resource Center, Peace Dialogue, Women's Rights Center, Armenian Young Women's Association. 2013. 2013 Civil Society Monitoring Country Report on Implementation of United Nations Security Council Resolution 1325 "Women, Peace and Security." www.equalpowerlastingpeace. org/download/1325imp_report_Armenia_2013.pdf

Kronsell, Annica. 2012. Gender, Sex, and the Postnational Defense: Militarism and Peacekeeping. Oxford, New York: Oxford University Press.

Leach, Katherine. 2014. "UNSCR 1325 in Practice: Women in the Military." http://blogs.fco.gov.uk/katherineleach.

McLeod, Laura. 2011. "Configurations of Post-Conflict: Impacts of Representations of Conflict and Post-Conflict upon the (Political) Translations of Gender Security within UNSCR 1325." International Feminist Journal of Politics 13(4): 594-611.

McLeod, Laura. 2016. Gender Politics and Security Discourse: Personal-Political Imaginations and Feminism in "Post-Conflict" Serbia. Abingdon, Oxon; New York: Routledge.

Moghadam, Valentine M. 2015. "Transnational Activism." Gender Matters in Global Politics: A Feminist Introduction to International Relations, ed. by L. Shepherd, 331346. New York: Routledge.

NATO. 2014. NATO/EAPC Action Plan for the Implementation of the NATO/EAPC Policy on Women, Pease and Security. North Atlantic Treaty Organization.

NATO. 2016. "NATO and Armenia Committed to Partnership." NATO, March 9. http:// www.nato.int/cps/en/natohq/news_129110.htm

News.am. 2016. "Armenia MOD: Nation, Army Concepts Need To Be Associated with One Another." News.am, October 11.https://news.am/eng/news/351167.html

Parashar, Swati. 2015. "War." Gender Matters in Global Politics: A Feminist Introduction to International Relations, ed. by L. Shepherd, 99-109. New York: Routledge.

Pratt, Nicola. 2013. "Reconceptualizing Gender, Reinscribing Racial-Sexual Boundaries in International Security: The Case of UN Security Council Resolution 1325 on 'Women, Peace and Security."' International Studies Quarterly 57(4): 772-783. 
Puechguirbal, Nadine. 2015. "Peacekeeping." Gender Matters in Global Politics: A Feminist Introduction to International Relations, ed. by L. Shepherd, 253-267. New York: Routledge.

Reeves, Audrey. 2012. "Feminist Knowledge and Emerging Governmentality in UN Peacekeeping: Patterns of Co-Optation and Empowerment." International Feminist Journal of Politics 14(3): 348-369.

Santos, Rita, Silvia Roque, and Tatiana Moura. 2013. "Missed Connections: Representations of Gender, (Armed) Violence and Security in Resolution 1325," trans. by Karen Bennett. RCCS Annual Review 5: 3-31.

Shahnazaryan, Gohar. 2015. "Women's Political Participation in Armenia: Institutional and Cultural Factors." Caucasus Analytical Digest 71: 9-13.

Shepherd, Laura J. 2008. Gender, Violence and Security Discourse as Practice. London: Zed Books.

Shepherd, Laura J. 2010. "Women, Armed Conflict and Language - Gender, Violence and Discourse." International Review of the Red Cross 92(877): 143-159.

Shepherd, Laura J. 2015. "Peacebuilding." Gender Matters in Global Politics: A Feminist Introduction to International Relations, ed. by L. Shepherd, 268-281. New York: Routledge.

Shepherd, Laura J. 2016. "Making War Safe for Women? National Action Plans and the Militarisation of the Women, Peace and Security Agenda." International Political Science Review, 37 (3): 324-335.

Sylvester, Christine. 2012. War as Experience Contributions from International Relations and Feminist Analysis. Hoboken: Taylor and Francis.

The Kvinna till Kvinna Foundation. 2012. Armenia and Azerbaijan: Stuck in Conflict over Nagorno-Karabakh. www.equalpowerlastingpeace.org/download/ Popular_version_Armenia_Azerbaijan.pdf

UN Women. 2015. "High-Level Review on Women, Peace and Security: 15 Years of Security Council Resolution 1325." UN Women, October 12. http://africa.unwomen. org/en/news-and-events/stories/2015/10/women-peace-and-security

UNFPA. 2015. "Workshop on Implementation of UNSC Resolution 1325: Experience of Armenia." UNFPA, November 5. http://armenia.unfpa.org/en/news/workshopimplementation-unsc-resolution-1325-experience-armenia\#sthash.kfmalN7g. dpuf

United Nations Security Council. 2000. Resolution 1325. https://documents-dds-ny. un.org/doc/UNDOC/GEN/N00/720/18/pdf/N0072018.pdf?OpenElement

Wright, Hannah. 2015. "Ending Sexual Violence and the War System - Or Militarizing Feminism?" International Feminist Journal of Politics 17(3): 503-507.

Zajović, Staša, ed. 2010. Women, Peace, Security: Resolution 1325 - 10 Years. Belgrade: Women in Black - Belgrade. 